\title{
BUDGET FEDERALISM AS AN INTEGRAL PART OF UKRAINE'S GLOBALIZATION INTEGRATION
}

\author{
Iryna P. Ustynova ${ }^{1}$ \\ Iryna A. Tolkachova ${ }^{2}$ \\ Sofiia Ya. Lykhova ${ }^{3}$ \\ Olga A. Husar ${ }^{4}$ \\ Viacheslav V. Stepanenko 5
}

\begin{abstract}
The relevance of the researched problem is conditioned by the civilizational need of globalization entry of Ukraine in the European and world community with further reforming of its system of state administration in the financial sphere. The purpose of the article is based on the study of current world experience and the consequences of budget federalization as a phenomenon, analysis of the current reform situation in Ukraine and the development of useful recommendations for further approbation. The basic method is comparative, which allowed to compare different state and legal systems, in order to identify similarities or differences between them, resulting in a qualitative state of the legal system as a whole and individual legal institution. This allowed us to consider the
\end{abstract}

problem in a holistic manner and from every side. The article analyzes the policy and experience of budget federalism of Ukraine and other countries, analyzes the development of budget legislation of Ukraine and develops recommendations for the Ukrainian legislator for further structural changes in the administration of the financial sector. It is claimed that Ukraine has done significant work in adapting its legislation to European and world practices through the introduction of budget (fiscal) federalism. Recommendations, analysis and review are aimed at adaptation of Ukrainian legislation to world economic systems during the process of globalization and embedding Ukraine in it. The materials of the article can be useful to anyone who researches federalism.

\footnotetext{
${ }^{1}$ Department of Constitutional and Administrative Law, National Aviation University, 03058, 1 Liubomyr Huzar Ave., Kyiv, Ukraine. E-mail: ustynova551422@uohk.com.cn

${ }^{2}$ Department of Constitutional and Administrative Law, National Aviation University, 03058, 1 Liubomyr Huzar Ave., Kyiv, Ukraine.

${ }^{3}$ Department of Criminal Law and Process, National Aviation University, 03058, 1 Liubomyr Huzar Ave., Kyiv, Ukraine.

${ }^{4}$ Department of Constitutional and Administrative Law, National Aviation University, 03058, 1 Liubomyr Huzar Ave., Kyiv, Ukraine.

${ }^{5}$ Department of Law, Kryvyi Rih National University, 50027, 11 Vitaly Matusevich Str., Kryvyi Rih, Ukraine.
} 


\section{।}

i.

GÊNERO E

INTERDISCIPLINARIDADE

Keywords: economic governance, budgetary policy, intergovernmental relations, intergovernmental equalization.

\section{INTRODUCTION}

In the modern conditions of the implementation of the concept of European integration and the spreading of globalization, one of the priority issues is the study and understanding of the application of an array of European legislation. This will significantly affect the system of international economic relations, and in the future will strengthen the position of Ukraine among countries with a high level of economic development. In turn, a new, rational construction of a mechanism for redistribution of financial resources will help to achieve sustainable economic development, in which decentralization reform will determine the priority of preserving economic potential between regions. To ensure socioeconomic development in Ukraine, it is necessary, first of all, to determine an effective way to improve intergovernmental relations. In this aspect, the issue of implementing the principles of budget federalism in Ukraine is relevant.

Nowadays, the problem of effective redistribution of resources to increase the quality of public administration, which
Vol no 02 | no 01 | ISSN: 2675-7451

https://www.periodicojs.com.br/index.php/gei/index

involves the redistribution of power between the center and the administrative-territorial units accountable to the center within one state, has become extremely relevant. These mechanisms are attributed to the system of decentralized management, which has become widespread in both federal and unitary states. Thus, the effective organization of relations between the budgets of local governments and the government is an important problem of public finances, which is influenced by various factors, which are clearly manifested in the relationship of budget federalism. Factors of influence are related to the fact that the system of fiscal relations between different authorities can theoretically be based on different combinations of levels of decentralization in different areas.

Federal states find solutions to problematic issues of compliance with the requirements of federal entities and the division of tax resources using a variety of methods (the most common are formula calculations), depending on the model of government and the level of decentralization. However, the accumulated experience in the application of formula calculations also revealed unresolved problems, namely the lack of a direct link between the size of equalization grants and the main macroeconomic indicators of the development of administrativeterritorial units; the mechanism of calculation 


\section{I}

.

CEANERO E
INTERDISCIPLINARI

of equalization subsidies does not fully take into account the regional specifics of the territories.

To characterize the complex structure of public administration, in which each link receives an individual budget and performs its functions within the budgetary powers assigned to it, use the term "federalism". This definition is used to formulate relations in federations, but today it is applied to countries that are not federal states under the constitution. Federalism is a way of public administration in which the interests of the whole state are organically combined with the interests of its individual parts, while maintaining the independence of the territories included in their competence in resolving issues ensures the unity and integrity of the country. As a result, the combination of the principles of fiscal federalism between levels of government in the centralized type is characterized by the separation of powers over expenditures and is not accompanied by endowing them with sufficient own sources of income. Financing of territorial programs in these conditions is carried out with use of various forms of interbudgetary relations at the expense of the centralized means of the federal budget. Here, the independence of the lower divisions of the budget sector is minimized. Decentralized types of organization of the budget system are based on the recognition of
Vol no 02 | n $^{\circ} 01$ | ISSN: 2675-7451

https://www.periodicojs.com.br/index.php/gei/index

a high degree of independence of regional and local budgets. Powers in the area of expenditures correspond to powers in the area of revenues.

Carrying out a unified economic and financial policy within Ukraine is a difficult issue in modern conditions. Decentralization can negatively affect the ability of federal governments to control the macroeconomic processes of regional and local governments. Authorities may come into conflict in the process of performing their tasks. Fiscal federalism is not limited to territorial redistribution of resources in the form of financial assistance, its purpose is also to ensure the self-sufficiency of territorial formations, to stimulate their own efforts of communities to build economic potential. Fiscal federalism performs important political and social functions. The movement of budgetary resources in the direction from the territories to the center unites regions with different financial and economic potential into a single state body and thus unites the nation.

Another important issue that needs to be enshrined in law is the economic relations of heads of government in regions that tend to put their own priorities above the interests of the state. Ensuring the implementation of measures for the effectiveness of economic issues, solving the problems of territorial justice, ensuring political stability is the main 


\section{I}

GENERO E

INTERDISCIPLINARIDADE

goal of budget federalism. Its implementation should be ensured by the establishment of regulatory budgetary rights and responsibilities. They should arise at all stages of the budget process from three equal parties - local, federal, regional and government, which are designed to ensure sufficient fairness and transparency in the redistribution of budget resources.

The purpose of the article is based on the study of current world experience and the consequences of budget federalization as a phenomenon, analysis of the current reform situation in Ukraine and the development of useful recommendations for further approbation.

\section{MATERIALS AND METHODS}

The concept of budget federalism is a manifestation of territorial democracy as an idea of federalism. Federal states solve with the help of various methods the problem of distribution of tax resources and satisfaction of the requirements of subjects depending on the model of public administration and the level of decentralization. In many unitary countries, certain principles of fiscal federalism have been actively applied in the field of internal financial intergovernmental relations. This concerns the definition of competence and the distinction between different levels of
Vol no 02 | nº 01 | ISSN: 2675-7451

https://www.periodicojs.com.br/index.php/gei/index

government. The central government, through relevant associations, makes extensive use of the mechanism of consultation with regional and local authorities. Fiscal autonomy of regional and local authorities is expanding. Financial and economic decentralization led to the formation of a new mixed type of intergovernmental internal financial relations, combining the principles of budgetary federalism and unitarism. The basic principles of federalism include: unity of the system of state authorities; territorial approach to state building; the integrity of the sovereignty of the state and the lack of it in its components; unity of economic and social systems of the state. Federalism reflects the structure of relations, which must peacefully resolve conflicts that arise between regional and state authorities, to influence their interaction, to provide the maximum in modern conditions, the method of governing the state.

Fiscal federalism is both a form of internal intergovernmental financial relations and a certain philosophy of organizing political relations between different levels of government. There are two main groups of models of budget federalism - decentralized and cooperative. Decentralized model is characterized by significant fiscal autonomy of regional local governments, weak links between different levels of government, and relatively limited cooperation, such as in the 


\section{I}

\section{GENERO E}

INTERDISCIPLINARIDADE

United States. Cooperative model is characterized by close cooperation between different levels of government, active policy of the central government with overcoming fiscal imbalances at different levels of government and financial equalization. Under such models of fiscal federalism, the central government is actively concerned about ensuring uniform standards of public services throughout the country. Cooperative models of fiscal federalism are characteristic of most federal European states. These include Germany and Austria. In equal shares, budget federalism affects both unitary and federal states. In federations, the financial system is a component of fiscal federalism. As for the essence of budget federalism, the distribution of economic resources between the various elements of power should be the most appropriate to the existing conditions, and spending money as appropriate and efficient.

Financial flows from the center to places with different economic potentials consolidate the regions into a single state body. The organization of budget regulation in the country directly depends on the state system. In unitary countries, the budget system is almost always centralized, and at a high level, local budgets are small in size, financial flows from center to place - significant. The budgetary federalism of each country has its own characteristics. For example, in Germany,
Vol n 02 | nº 01 | ISSN: 2675-7451

https://www.periodicojs.com.br/index.php/gei/index tax legislation is fully centralized, and the distribution of taxes between levels of the budget system is enshrined in the Constitution. According to Ye.O. Balatskyi (2009), certain principles of fiscal federalism have been actively applied in many unitary countries in the field of internal intergovernmental financial relations. This concerns the distinction between different levels of government expenditures and the competence to implement them. The central government makes extensive use of the mechanism of consultation with local and regional authorities through relevant associations. The fiscal autonomy of local and regional authorities has expanded. Economic and financial decentralization, today characteristic of most foreign unitary countries, led to the formation of a new mixed type of internal intergovernmental financial relations, combining the principles of both budgetary unitarism and budgetary federalism.

In the fight against the aggravation of the functions of the institution of modern selfgovernment, the most effective and rapid process is the introduction of a model of fiscal or budgetary federalism. Its purpose is to create organizational, economic and legal bases for ensuring the financial independence of budgets at the city level, the qualified implementation of local government powers and the provision of accessible, timely public 


\section{I}

GENNERO E

INTERDISCIPLINARIDADE

services. In our opinion, it is worth noting that budget federalism can be practically terminated as a normative establishment of the relationship between local government and central government on the basis of the division of expenditure powers and revenue sources for public services on the basis of the highest expediency, accessibility, maximum quality, budget, essential observance of the principles of financial independence of each element of power.

\section{RESULTS}

\subsection{Issues of General Decentralization}

\section{Reform in Ukraine}

Ukraine is a unitary state, a single state entity consisting of administrative-territorial units that are subordinated to central authorities and have no signs of state independence and are based on the supremacy of sovereignty. The central government monitors the implementation of all public functions in its territory, where there are common authorities for all, ensuring the unity of the public administration process. In the construction of inter-budgetary relations of Ukraine is laid not only the model of unitarism, but also the following elements of federalism:

- independence of local budgets, which provides for the consolidation of the budgets of each level of the budget system of the relevant
Vol no 02 | no 01 | ISSN: 2675-7451

https://www.periodicojs.com.br/index.php/gei/index

sources of income, the list of which is determined by law;

- the right of the relevant bodies to determine the directions of use of budget funds in accordance with the legislation of Ukraine;

- the right of independent and autonomous consideration and approval of each of the budgets (The Budget Code of Ukraine, 2010).

The primary issues of implementation of the policy of budget federalism in Ukraine are: passivity of local governments; lack of professional training and lack of real initiatives for territorial development; concentration of power in the center, as a consequence, limited human resources in regional bodies; introduction of the principles of socialized integration in the budget strategy of local authorities; substituting the state expediency of actions for lobbying one's interests by higher levels of government. Based on the above, it can be argued that further budget decentralization should take place after changes in the system of public administration, tax system and social protection. For this process it is necessary to solve the main problems of introduction of budgetary federalism in Ukraine, namely: uneven pace of socio-economic development of regions; a wide list of social obligations declared by the state; high level of rotation and subsidiarity of local budgets; insufficient revenue of local 


\section{I}

\section{GÊNERO E}

INTERDISCIPLINARIDADE

budgets. Characteristics of the basic principles that reflect the essence of fiscal federalism determines that their implementation and consolidation is likely in Ukraine because its purpose is to obtain at minimal cost of public services to citizens with observance of the basic principles of independence of each degree of power in the direction of achievement of economic independence, reform of tax and budgetary policy, both in local governments, and in the central government.

In each country where the concept of fiscal federalism is implemented, it provides for a combination of two complementary trends - equalization of competition and ensuring minimum national standards throughout the country and competition in the social services market between regional authorities. Achieving justice through the redistribution of financial resources in ensuring the prospects for the development of specific administrative units due to the need to develop and apply methodological support and scientific justification. For this purpose, it is necessary to apply long-term experience of the developed countries of the world concerning budgetary federalism. At the same time, it is necessary to start smoothing the difference in the levels of economic and social development of territories to provide their residents at the minimum level of state guarantees, as well as
Vol no 02 | nº 01 | ISSN: 2675-7451

https://www.periodicojs.com.br/index.php/gei/index to increase revenue mobilization to the relevant budget to stimulate local government. A detailed study of the concept of "budget federalism" gave us reason to consider it as a statutory relationship between central government and local government on the distribution of revenue sources and expenditure powers to finance, provide public services based on their quality, accessibility, feasibility, demand and cost-effectiveness with mandatory observance of the principle of financial independence of each level of government.

Implementation of the basic principles of budget federalism and their observance is quite possible in Ukraine, as its purpose is to provide citizens with public services at the lowest price in accordance with the principle of independence of each level of government in fiscal policy, achieving financial independence of both central government and local government. Thus, the introduction of not only budget decentralization, but also its highest degree - budget federalism - in Ukrainian practice, will provide an opportunity to "cut off the tops" of economic, political, ethnocultural contradictions between regions of Ukraine, encouraging them to self-development and allowing them to pursue their own budget policy aimed at meeting the needs of the population in obtaining quality and affordable public services. 


\section{INTERDISCIPLINARIDADE}

On September 16, 2014, Ukraine made its choice by ratifying the Association Agreement with the European Union (hereinafter - the EU). Among the key reforms that will implement the Association Agreement between Ukraine and the EU, of course, is the reform of legislation with further improvement of civil society regulation in general, and the decentralization of public administration through decentralization in the financial and budgetary systems. According to I.P. Ustynova et al. (2016), decentralization of power is an integral part of the existence of a democratic society. The decentralization processes that have taken place in Ukraine have only just begun the first step-by-step steps towards the transition of public finance management to the principles of fiscal federalism, although some provisions still need practice and editing. Undoubtedly, for the effective introduction of decentralization processes, which are quite long and complex, it is advisable to amend the Basic Law, which would contribute to the creation of a European model of local self-government, regulate factors affecting various spheres of society, namely: budget, tax, education, land, health policy, housing and communal services, etc. When considering the problems of decentralization, it is important to find a balance between centralization and decentralization as the need to ensure the effective operation of local and central government. It is clear that decentralization as a method of governance is aimed at the development of territories and local democracy. Reasons for the transfer of more powers to local governments include greater efficiency and accountability of local governments, better prospects for local development, as well as the introduction of democracy and increased protection of human rights. Today in Ukraine, unfortunately, one of the most acute problems is the low standard of living. The most critical aspect can be identified socio-economic, characterized by backwardness of economic management, declining activity of society, the decline of potentially important areas of the economy. Reforms in Ukraine need to be carried out based on the needs and goals of society, a clear understanding of what result is expected of them.

Decentralization is due to Ukraine's desire to increase the level of provision and provision of state standards and services, eliminate economic instability, and accelerate the social and economic development of the state. Democratically developed countries have gone through this process at different times, therefore, the issue of decentralization at the present stage of reforming the system of governance of Ukraine is inextricably linked with the theoretical understanding of the 


\section{I}

GEN NERO E

INTERDISCIPLINARIDADE

concept and historical experience of these processes. The experience of foreign countries suggests that when defining decentralization measures it is necessary to take into account the principle of subsidiarity, which largely characterizes and reveals the content of this process at the present stage of development of society. As rightly noted by L. Vasylenko (2017), this principle creates the basis for the decentralization of public authority, as it involves the transfer of decision-making powers from the central to the lower organizational levels. The implementation of this course should become one of the dimensions of harmonization of approaches to the organization of public authorities and local self-government of Ukraine in accordance with the standards and principles of developed democracies. Solving the problem of division of powers between the executive and local governments in accordance with the essence of the rule of law, democracy and civil society will allow achieving a balance of interests in the system of relations "state - region territorial community". As for the decentralization of power in the understanding of financiers, it is budgetary or fiscal decentralization (or decentralization of financial resources).

The centralized system has an asymmetric distribution of resources between different regions, inertia of economic policy of
Vol no 02 | nº 01 | ISSN: 2675-7451

https://www.periodicojs.com.br/index.php/gei/index

local authorities, low efficiency of budget funds, lobbying and high levels of corruption. It is clear that decentralization in the financial and budgetary systems in Ukraine is a complex issue, which many scholars have paid attention to. This multiplicity of views allows us to judge the ambiguity of this process and creates a problem of its study at the theoretical level. First of all, decentralization of power is a change in the system of government from monopoly-hierarchical to partnershiphorizontal, in which a significant part of the functions of central government is transferred to local authorities and initiative selforganization of citizens, the centralization of power is abolished or weakened. Thus, there is a necessary process of expanding and strengthening the rights and powers of administrative-territorial units while narrowing the rights and powers of the center. This is done in order to optimize and improve management efficiency and the fullest realization of regional and local interests.

Scholars distinguish two models that describe relations within the state - the model of partnership and mediation. The choice of a particular model is determined primarily by the history of the state. States that were formed through the unification of individual parts (communities) for mutual assistance and protection (Switzerland, the Netherlands, England) build a model of partnership. This 


\section{I}

\section{.}

GÊNERO E

INTERDISCIPLINARIDADE

model is characterized by an understanding of the importance of local government as a mechanism for achieving the interests of citizens of a particular area or community. So, in Switzerland there are more than 3 thousand municipalities, in the USA more than 80 thousand local authorities.

The second model is inherent where the country has historically been shaped by authoritarian tendencies. In these states, local government was generally seen as a subordinate intermediary, and all-important areas of social relations were controlled by the center, significantly limiting the functions of local government. In such a situation, it is assumed that the state should be the guarantor of socio-economic stability, and can protect the community from inefficient use of local resources and excess power on the ground. This also applies to Ukraine. Thus, by the order of the Cabinet of Ministers of Ukraine of April 1, 2014 and the draft Law of Ukraine "On Amendments to the Constitution of Ukraine (on decentralization of power)" the Concept of reforming local self-government and territorial organization of power in Ukraine was submitted for discussion (Order of the Cabinet of Ministers... 2019). This document highlights aspects of the issues that concern the community and local government leaders the most. They relate to purely management
Vol no 02 | n $^{\circ} 01$ | ISSN: 2675-7451

https://www.periodicojs.com.br/index.php/gei/index

issues, but in particular, regarding financial and legal issues are as follows:

- filling local budgets (they are independent, i.e. not included in the State Budget of Ukraine and in case of lack of funds from the State Budget under intergovernmental regulation sent intergovernmental transfers in the form of equalization grants, which was determined by the formula method);

- the growth of the powers of the community can take into account the possibility for resource filling of the local budget, and they do not have the primary financial resources to launch certain projects and programs;

- there is a situation on the organization and implementation of other methods of financial control by the state for the management of local funds;

- there is no clear definition of the level of subsidiarity, resulting in problems at the level of communities, district and Regional councils, which will fight for their own independence and the ability to manage through the allocation of additional funding.

The next step in decentralization in Ukraine was the laws "On Voluntary Association of Territorial Communities" and "On the Principles of State Regional Policy" (Law of Ukraine No. 156-VIII, 2015). These laws are designed to overcome the problem of 


\section{I}

GENERO E

INTERDISCIPLINARIDADE

limited capacity of local authorities and will allow moving to the planning of infrastructure projects at the local level. The new system envisages radical changes in the formation of revenue and expenditure parts of local budgets, the definition of the principles of transfer policy and the organization of inter-budgetary relations. The main tasks of such a system and ways to implement it are:

- ensuring budgetary autonomy and financial independence of local budgets;

- autonomy of local budgets guaranteed by the Constitution of Ukraine, i.e. independent formation of local budgets, and not on the principle of "top-down" or "downtop" (Constitution of Ukraine, 1996);

- independent formation and approval of local budgets (the budget process will not depend on the adoption of the state budget);

- initiating the transition from a threetier to a two-tier budget model;

- assigning a stable income base for each level of self-government (community, district, regional) to implement their functions and stimulate tax-capable communities;

- free (within the limits set by the Tax Code of Ukraine, 2010) regulation by local governments of rates of local taxes and fees;

- abolition of the mechanism of withdrawal of funds to the state budget;

- opportunities for transition to banking services for local budget managers, etc.
Vol n 02 | nº 01 | ISSN: 2675-7451

https://www.periodicojs.com.br/index.php/gei/index

Thus, in our opinion, only the given list of possible, unresolved problems of distribution of powers and finances can lead to the issue of administrative structure of the state, i.e. federalization of the country, and this is not a historically determined path of Ukraine's development.

According to scientists and experts, when 60 to $80 \%$ of financial resources are left on the ground, we can talk about real decentralization of power. According to N.O. Bykadorova (2010) it is envisaged that at the first stage of solving communal problems, financing of medicine, education, social issues that will place a heavy burden on communities, districts and regions, through state educational, communal, medical subventions, i.e. targeted transfers for the specific purpose of spending money.

It is appropriate to support the warning of N. Slavinskaite, M. Novotny, D. Gedvilaite (2020) that the decentralization of the budget process may lead to an imbalance of the entire system of budget formation in Ukraine. Although the fiscal decentralization in the European Union has yielded interesting and visible results. For example, in Bulgaria and Lithuania today the lowest rates of fiscal decentralization are 13 in the EU (0.28), and in the Czech Republic - the highest (0.46). The level of economic development of these countries is known to be significantly different 


\section{I}

\section{GÊNERO E}

INTERDISCIPLINARIDADE

and this is a useful experience for Ukraine. Therefore, for the current 2020, in the regions, on average, $60 \%$ of taxes are left against $30 \%$, which remained earlier.

\subsection{Current State of Organization and} Implementation of Decentralization in Ukraine

In Ukraine, as in most countries, there is intergovernmental regulation in the form of intergovernmental transfers. Thus, the Budget Code of Ukraine states that inter-budget transfers are funds that are transferred free of charge and irrevocably from one budget to another (The Budget Code of Ukraine, 2010).

In accordance with Art. 96 of the Budget Code, intergovernmental transfers are divided into: basic subsidy (transfer provided from the state budget to local budgets for horizontal equalization of tax capacity of territories); subventions; reverse subsidy (funds transferred to the state budget from local budgets for horizontal equalization of tax capacity of territories); additional grants. The Budget Code of Ukraine also provides for such types of intergovernmental transfers as: basic subsidy, subventions for state social protection programs, additional subsidy to compensate for losses of local budget revenues due to state benefits, additional subsidy for maintenance expenditures transferred from the state budget educational and health care institutions,
Vol no 02 | no 01 | ISSN: 2675-7451

https://www.periodicojs.com.br/index.php/gei/index subvention for the implementation of investment projects; educational subvention.

Since there is such a phenomenon as budget transfers, the territorial communities of any territorial units have the opportunity to receive part of the income from the implementation of certain projects and, accordingly, reduce the need to receive funds directly from the state budget. Thus, the united communities have acquired the powers and resources that cities of regional significance have, in particular, the transfer to the local budgets of united territorial community of $60 \%$ of the personal income tax on their own powers. In addition, local revenues from taxes remain entirely: the single, the profit of enterprises and financial institutions of communal property and property tax (real estate, land, transport) (Decentralization reform, 2014).

The united territorial communities have direct inter-budgetary relations with the state budget. Before the reform, they had only regional and district budgets, budgets of cities of regional importance. In order to fulfill the powers delegated by the state, they are provided with appropriate transfers: grants, educational and medical subventions, subventions for community infrastructure development, etc. Legislative changes have also given local governments the right to approve local budgets regardless of the date of 


\section{I}

GENERO E

INTERDISCIPLINARIDADE

adoption of the law on the State Budget. The Budget Code of Ukraine also provides for such types of intergovernmental transfers as: basic subsidy, subventions for state social protection programs, additional subsidy to compensate for losses of local budget revenues due to benefits established by the state, additional subsidy for expenditures transferred from the state budget on the maintenance of educational and health care institutions; subvention for the implementation of investment projects; educational subvention.

Since there is such a phenomenon as budget transfers, the territorial communities of any territorial units have the opportunity to receive part of the income from the implementation of certain projects and, accordingly, reduce the need to receive funds directly from the state budget. Hence the new opportunities, namely the future implementation of the plan on the ground to facilitate the lives of local residents and improve the conditions for normal life. Thus, the united territorial communities have acquired the powers and resources that cities of regional significance have, in particular, the transfer to the local budgets of united territorial communities of $60 \%$ of the personal income tax on their own powers. In addition, revenues from taxes remain entirely on the ground: a single tax, on the profits of enterprises and
Vol no 02 | nº 01 | ISSN: 2675-7451

https://www.periodicojs.com.br/index.php/gei/index

financial institutions of communal property and property tax (real estate, land, transport).

The united territorial communities have direct inter-budgetary relations with the state budget. Before the reform, they had only regional and district budgets, budgets of cities of regional importance. In order to fulfill the powers delegated by the state, they are provided with appropriate transfers: grants, educational and medical subventions, subventions for community infrastructure development, etc. Legislative changes have also given local governments the right to approve local budgets regardless of the date of adoption of the law on the State Budget.

The legislator amended the Budget Code of Ukraine from 2014 to 2019. Such changes have already yielded the first results. Own revenues of local budgets from 2014 to 2017 increased by more than 100 billion hryvnias (The Budget Code of Ukraine, 2010). The growth rate of local taxes and fees in the united territorial communities is $29.4 \%$ (for 11 months of 2017), which is $24.9 \%$ higher than the average in Ukraine. In particular, the payment for land increased by $20 \%$, real estate tax revenues - by more than $70 \%$. Development budget expenditures per capita increased 1.5 times compared to last year (Decentralization reform, 2014).

The volume of financial resources of local budgets in 2018 compared to 2019 


\section{I}

列

CÊNERO E

INTERDISCIPLINARIDADE

increased by UAH 41.1 billion. or $17.6 \%$. The general fund of local budgets for 2019 received UAH 275 billion, or 101.9 percent of the annual revenue approved by local councils. In 2019, the volume of capital expenditures increased and amounted to UAH 99.8 billion, which is UAH 8.7 billion or 9.5 percent more than in the corresponding period of 2018. The share of capital expenditures in the total expenditures of local budgets (general and special fund together) increased compared to 2018 by 1.6 percent and is 17.6 percent (for comparison: in 2016-2017 the share of capital expenditures was 15.0 percent, in In 2015 11.5 percent, and in 2013-2014 - only 6.5 and 6.2 percent, respectively. All obligations for intergovernmental transfers have been fulfilled. In 2019, transfers from the State Budget of Ukraine to local budgets were transferred for the total amount UAH 261.4 billion, including transfers from the general fund - UAH 245.4 billion, of which: social protection subventions - UAH 79.3 billion, medical subvention - UAH 56.1 billion education subvention - UAH 70.4 billion, basic subsidy to strengthen the tax capacity of local budgets - UAH 10.4 billion (Information of the Ministry of Finance... 2019; The Ministry of Finance has published... 2020). According to the State Treasury Service, as of June 1, 2020 (Execution of the state budget... 2020), 48 types of subventions and subsidies
Vol no 02 | no 01 | ISSN: 2675-7451

https://www.periodicojs.com.br/index.php/gei/index

have been allocated from the state budget of Ukraine. Among them in terms of content and scale are such as "Stabilization grant" and "subvention for the construction of a preschool in Bucha, Kyiv region" and "Subvention to Valkiv district for the purchase of a computer tomograph." Thus, intergovernmental transfers affect a large number of processes in the state.

The current experience of economically developed countries (Australia, Canada, Germany, Switzerland) shows that fiscal decentralization is a procedure of equalization of regions, i.e. funds are allocated from the central budget to the regional level to overcome the budget deficit and the same level of development. The general trend is that regional changes in the size of payments are allowed until there is an important moment when wealthier regions diverge too far from the average. S. Brenton (2020) rightly argues that further reform processes are often lengthy, and in some cases attempts to identify richer regions, while federal government contributions increase rather than significantly affect the conditions or payments of key recipients.

Changes in the legislation make it possible to implement the policy of decentralization of powers and finances, as well as to strengthen the material and financial foundations of local self-government and give 


\section{I}

列

CÊNERO E

INTERDISCIPLINARIDADE

local budgets budgetary autonomy and financial independence, establish a new mechanism of budget equalization. On the positive side, the legislator simplifies the procedure for providing local guarantees and borrowing from international financial organizations, strengthens the responsibility of line ministries for the implementation of state policy in the relevant field and efficient use of budget funds, improves the treasury service of budget funds and provides an opportunity for local budgets to switch to the banking form of service of budget funds for the development of local budgets and own revenues of budget institutions.

When conducting decentralization in Ukraine, we believe that we should take into account the current experience that in Europe; federalism in the influence of fiscal decentralization on the stability of the budget has given indisputable results. But there are uncertain budget expectations. The level of severity of the adopted balanced budget rules varies in different countries depending on the established federal models. We agree with the position of R. Csehi (2020) that instead of decentralization itself, the combination of decentralization and interdependence between levels of government causes different levels of strictness to budget indicators in federal systems. With this in mind, budget programs for local budgets should be calculated,
Vol no 02 | nº 01 | ISSN: 2675-7451

https://www.periodicojs.com.br/index.php/gei/index

possibly using the ten-point scale in force in Europe.

\section{DISCUSSION}

For Ukraine, budgetary or fiscal federalism is too new a phenomenon in the system of state building and public administration. The history of the study of this phenomenon is an important component of Ukrainian reforms. The development of the idea of budget federalism is inseparable from the ideas of budget decentralization. This is reflected in the works of W. Outes (1972), R. Musgrave, G. Rosen (1999) and other world-famous scientists. As for domestic scholars and practitioners, most of them for a long time rejected the idea of the possibility of applying the concept of budget federalism in Ukrainian realities as a unitary state. But if we analyze the experience of EU states in recent decades, it clearly shows the feasibility of at least partial use of the principles of fiscal federalism in unitary states. In Sweden, Denmark and France, for example, they have become widely used.

Developed countries, in order to avoid the growth of interregional contradictions, are following the path of decentralization of power, giving the territories broader powers in the field of budget, finance, and tax administration. In the United Kingdom, not only Scotland but also Wales and Northern 


\section{I}

E

CEANERO E

INTERDISCIPLINARIDADE

Ireland have achieved considerable autonomy in addressing local issues. In Italy, Sardinia, Sicily, Trentino-Alto Adige, Valle d'Aosta, Friuli-Venezia Giulia have a special autonomous status. Today, in scientific circles, unfortunately, the unified interpretation of the concept of budgetary (fiscal) federalism is still not agreed, as evidenced by the diversity of views and opinions of foreign and domestic scientists.

J.E. Stiglitz (2005) argues that fiscal federalism is a financial interaction of different levels of government. According to P. Russell, fiscal federalism is the transfer of wealth through equal payments from those provinces that "have" to those "in need" in order to redistribute income to ensure acceptable levels of public service provision under more or less acceptable tax conditions (Suntsova, 2010). W.E. Oates states that "fiscal federalism is based on an understanding of which functions and tools should be best used at the central level and which at the local level of public administration". According to W.E. Oates budget federalism is a relationship based on a combination of principles of centralism and decentralization between the federal authorities and the authorities of the federation on the formation and implementation of state budget policy, delimitation of fiscal powers, expenditures and revenues, distribution of the latter between the federal budget and the
Vol no 02 | no 01 | ISSN: 2675-7451

https://www.periodicojs.com.br/index.php/gei/index consolidated budget of the subjects of the federation with low self-sufficiency of territorial budgets, based on the need to combine national interests and the interests of the population (Oates, 1972).

K.R. McConnell and S.L. Brue (2009) argue that fiscal federalism is a system of transfers (grants) on the basis of which the federal government shares its revenues with state and local governments. H.S. Rosen (1999) formulates that optimal budget federalism is the correct distribution of spheres of activity by governmental levels. L.I. Yakobson (1996) believes that budgetary federalism provides part of the independence not only in determining the needs for public goods, but also in finding resources to meet them. According to A.G. Igudin (2011), budgetary federalism is a relationship based on the relationship of the principles of centralism and decentralization between state and regional authorities on the formation and implementation of state budget policy, delimitation of fiscal powers, expenditures and revenues, distribution and redistribution the latter between the state budget and consolidated regional budgets with a high degree of independence of territorial budgets, based on the need for unity of national interests and the interests of the population living in the territories of the federation and their municipalities. V.L. Andrushchenko and 


\section{I}

GÊNERO E

INTERDISCIPLINARIDADE

O.P. Kyrylenko (2001) rightly believe that budget federalism is a legally established strategy for the distribution of functional powers and responsibilities of state, regional, local government with a compromise separation on this basis of revenues and expenditures between the budget system on principles of political activity, social ethics, interregional and interethnic solidarity.

Budget federalism, in our opinion, should be understood (interpreted) as a legally established relationship between central government and local governments on the distribution of sources of revenue and budget expenditures to finance public services, which should be carried out on the basis of their highest quality, maximum accessibility, expediency, demand and economy, with mandatory adherence to the principle of financial independence of each level of government. S.Yu. Khaminich and V.M. Klymova (2011) point out that the current theory of fiscal federalism considers the question of which is better: budget (fiscal) centralization or decentralization, and also argues that any decentralization processes reflect a complex scheme of relations between budgets of different levels. Unfortunately, so far neither economists nor lawyers have disclosed the criterion for determining the optimal level of centralization or decentralization of budget funds for the
Vol no 02 | nº 01 | ISSN: 2675-7451

https://www.periodicojs.com.br/index.php/gei/index

formation of revenue parts of the State and local budgets. It is the economic theory of fiscal federalism that must answer this question.

Critical analysis of the definition of "decentralization" in the works of many scientists proves that decentralization is a set of phenomena, the components of which are defined differently by different scientists. However, despite differing views on the definition of decentralization, the authors support the idea that it is fundamental to define it in the light of the relationship between central and local government, their different powers (fiscal, political, administrative, etc.). American scientist M. Bell (Suntsova, (2010) argues that decentralization is a way of measuring the magnitude of the transition of the national economy from administrativecommand to market. The beginning of decentralization through the prism of various kinds of powers is that these powers have their own dimension and goals. In turn, financial decentralization is the process of dividing functions, financial resources and responsibility for their use between central and local government. In foreign countries, instead of "financial" use the term "fiscal decentralization". The founder of the latter idea was the American economist $\mathrm{Ch}$. Thibault (2019). According to him, it is fiscal decentralization that allows local governments 


\section{I}

ta

GENERO E

INTERDISCIPLINARIDADE

to gain autonomy in financing and providing public services. He proved that only with the fiscal autonomy of local governments will public spending meet the individual preferences of consumers according to their needs.

According to S.Ya. Likhova and I.P. Ustynova (2016), the English economist W. Oates made a significant contribution to the development of the theory of financial decentralization. He proposed the following definition: "decentralization is the right of independent decision-making by decentralized units." Regional and local authorities have the opportunity to make their own decisions on financial and land management issues. The authors also contributed to the study and adaptation of the theory of budgetary (fiscal) federalism in their publications, but they considered the legal aspects of reforming Ukrainian legislation, which have significant differences from economic and political science research.

\section{CONCLUSIONS}

Ukraine has made significant strides in fiscal decentralization. The legislator:

- a new procedure for budgetary legal relations has been defined within the framework of local self-government reform and territorial organization of power based on
Vol no 02 | nº 01 | ISSN: 2675-7451

https://www.periodicojs.com.br/index.php/gei/index

decentralization of power and significant expansion of powers of territorial communities (territorial communities will have the same powers as cities of regional significance and direct intergovernmental relations with the state budget);

- new types of transfers were introduced with the definition of the mechanism of distribution and use in terms of administrativeterritorial units (basic subsidy, educational subvention, subvention for training, medical subvention, subvention for medical measures of individual state programs and complex program measures. distributed among the relevant budgets on the basis of a formula approved by the Cabinet of Ministers of Ukraine);

- the revenue base of local budgets was expanded by fixing (or increasing the percentage) certain tax payments and fees to local budgets;

- the right to independently choose an institution (in the bodies of the Treasury or banking institutions) to service the budget of local budgets and own revenues of budgetary institutions;

- the order of treasury servicing of budget funds is regulated;

- the responsibility of the main managers of budget funds is strengthened;

- regulated budget relations in a special period (under martial law), including the 


\section{I}

GEN NERO E

INTERDISCIPLINARIDADE

expansion of certain powers of the Cabinet of Ministers of Ukraine, in particular to reduce budget expenditures and direct them to the expenditure of the reserve fund, public procurement, etc.

The Ukrainian legislator has fully used the successful experience of budget reforms in Poland and Germany, so further progress of Ukraine to the European community should be carried out subject to the completion of constitutional reform at the level of territorial organization, in accordance with the European Charter of Local Self-Government and decentralization.

Thus, in Ukraine the process of fiscal decentralization is quite active, consistent, with a fairly complete regulatory development of this process, which is a positive step in Ukraine's historical development, both local and state. Legal regulation of financial activity of local self-government bodies in the conditions of changes of interbudgetary relations needs further development and research for the purpose of creation of the clear financial legal mechanism of financial system of Ukraine.

Materials of research can be useful to scholars, lawyers, economists, public administration professionals, as well as practitioners, the public sector, and those researching federalism.
Vol no 02 | nº 01 | ISSN: 2675-7451

https://www.periodicojs.com.br/index.php/gei/index

\section{References}

Andrushchenko, V.L., Kyrylenko, O.P. Federalism of intergovernmental relations: foreign models and domestic problems. Entrepreneurship, Economy and Law, 2001, 7, 91-94.

Balatskyi, Ye.O. Features of budget federalism in some countries. Bulletin of the Ukrainian Academy of Banking, 2009, 2(27), 118-120.

Brenton, S. The price of federation: Comparing fiscal equalization in Australia, Canada, Germany and Switzerland. Regional \& Federal Studies, 2020, 30(1), 93-111. DOI: 10.1080/13597566.2019.1658082

Bykadorova, N.O. Financial decentralization of local self-government. Economic Bulletin of Donbass, 2010, 2(20), 145-151.

Constitution of Ukraine. 1996. https://zakon.rada.gov.ua/laws/show/254\%D0 \%BA/96-\%D0\%B2\%D1\%80\#Text.

Csehi, R. Federalism and the stringency of balanced budget rules - A comparative study of Canada, the European Union, and the United States of America. Regional and Federal Studies, $\quad 2020, \quad 30(1), \quad$ 73-91. DOI:10.1080/13597566.2019.1611563 
Vol no $02\left|n^{\circ} 01\right|$ ISSN: 2675-7451

https://www.periodicojs.com.br/index.php/gei/index
Decentralization reform. 2014.

https://www.kmu.gov.ua/diyalnist/reformi/efe

ktivne-vryaduvannya/reforma-

decentralizaciyi

Execution of the state budget in terms of intergovernmental transfers. 2020. https://www.treasury.gov.ua/ua/filestorage/2020-7.

Igudin, A.G. On the principles of reforming interbudgetary relations in the Russian Federation. Finance, 2011, 8, 6-9.

Information of the Ministry of Finance of Ukraine on the implementation of the State Budget of Ukraine for 2019. 2020. https://ukurier.gov.ua/uk/articles/informaciyaministerstva-finansiv-ukrayini-pro-vik/.

Khaminich, S.Yu., Klymova V.M. Features of fiscal decentralization in the conditions of development of the national economy of Ukraine. Bulletin of Dnipropetrovsk University, 2011, 5(2), 148-158.

Law of Ukraine No. 156-VIII "On the principles of state regional policy". 2015, February.

https://zakon.rada.gov.ua/laws/show/156-

19\#Text.

Lykhova, S.Ia., Ustynova, I.P. Legal characteristics of budget federalism and decentralization processes in Ukraine. Scientific works of the National Aviation
University. Series: Legal Bulletin "Air and Space Law", 2016, 2(39), 86-92. DOI: $10.18372 / 2307-9061.39 .10638$.

McConnell, K.R., Brue, S.L. Economics: Principles, Problems and Politics. Moscow: Respublika, 2009.

Oates, W.E. Fiscal federalism. New York: Harcourt, Brace, 1972.

Order of the Cabinet of Ministers of Ukraine No. 77-p "On approval of the action plan for the implementation of a new stage of reforming local self-government and territorial organization of power in Ukraine for 20192021”. 2019, January. https://zakon.rada.gov.ua/laws/show/77-2019$\%$ D1\%80\#Text.

Rosen, H.S. Public Finance. New York: Irwin McGraw-Hill, 1999.

Slavinskaite, N., Novotny, M., Gedvilaite, D. Evaluation of the fiscal decentralization: Case studies of European Union. Engineering Economics, 2020, 31(1), 84-92. DOI:10.5755/j01.ee.31.1.23065.

Styhlits, D.E. Public sector economy. Kyiv: Osnovy, 2005.

Suntsova, O.O. Local finances. Kyiv: Tsentr uchbovoi literatury, 2010.

Tax Code of Ukraine. 2010. https://zakon.rada.gov.ua/laws/show/275517\#Text. 
The Budget Code of Ukraine. 2010. https://zakon.rada.gov.ua/laws/show/245617\#Text.

The Ministry of Finance has published a report on the implementation of the State Budget for 2019. 2020. https://mof.gov.ua/uk/news/minfin_opublikuv av_zvit_pro_vikonannia_derzhavnogo_biudz hetu_za_2019_rik-2049.

Ustynova, I.P., Yakivchuk, Zh.V. Transfer issues in the public administration of Ukraine. Scientific works of the National Aviation University. Series: Legal Bulletin "Air and Space Law”, 2019, 1(50), 92-97.

Ustynova, I., Riabovolenko, I., Pestsov, R. Some theoretical questions of the legal contents of the financial and legal decentralization in Ukraine. Scientific Journal “Chronicles of KUL”, 2016, 1, 107-110.

Vasylenko, L., Dobrovinskyi, M. Decentralization and local government reform. Entrepreneurship, Economy and Law, 2017, 3, 123-126.

Yakobson, L.I. Public Sector Economics: Fundamentals of Public Finance Theory. Moscow: Aspekt Press, 1996. 